\title{
Oculocerebral Hypopigmentation Syndrome Maps to Chromosome 3q27.1q29
}

\author{
E. Chabchoub ${ }^{a, b} \quad$ O. Cogulu ${ }^{c} \quad$ B. Durmaz ${ }^{c} \quad$ J.R. Vermeesch ${ }^{a} \quad$ F. Ozkinay ${ }^{c} \quad$ J.-P. Fryns ${ }^{a}$ \\ ${ }^{a}$ Centre for Human Genetics, University Hospital Gasthuisberg, Leuven, Belgium; ${ }^{b}$ Department of Genetics and \\ Immunology, Research Unit 04UR0805, Faculty of Medicine, University of Sousse, Sousse, Tunisia; ' Department of \\ Paediatrics, Ege University, Izmir, Turkey
}

\section{Key Words}

Oculocerebral hypopigmentation syndrome $\cdot$ Cross syndrome $\cdot$ Array comparative genomic hybridisation Chromosome $3 q \cdot$ Deletion - Candidate gene $\cdot$ Genetic skin disease notype correlations and suggest candidate genes for this disorder. Conclusion: Investigating further patients would enable finemapping the OCHS locus and identifying its putative gene.

Copyright @ 2012 S. Karger AG, Base

\section{Introduction}

In 1967, Cross et al. [1] reported 4 siblings of a highly inbred Amish family with a combination of four major abnormalities: (i) cutaneous hypopigmentation, (ii) growth deficiency, (iii) severe ocular anomalies, and (iv) neurologic signs. The syndrome presents at birth with pigmentary and ocular anomalies including microphthalmia, exophthalmia, corneal and lens opacity, spastic ectropium, and nystagmus. The neurologic abnormalities are progressive and characterised by severe intellectual disability (ID), spastic diplegia, hyperreflexia, hyperirritability, and athetoid movements. These clinical features vary among affected individuals. This novel entity is known as oculocerebral hypopigmentation syndrome (OCHS) or Cross syndrome (OMIM 257800). A similar condition was described in 1983 by Preus et al. [2] in 2 sisters, born to consan- guineous Italian parents, both presenting skin and hair hypopigmentation, dolichocephaly, cataracts, high arched palate, deafness, and severe ID. The older sister also had growth retardation, small widely spaced teeth, finger contractures, spasticity, hypochromic anaemia, myopia and moderate hydrocephalus of the lateral ventricles. This intrafamilial heterogeneity was also reported by Fryns et al. [3] with 3 siblings presenting pure cutaneous hypopigmentation for a 23-year-old otherwise normal male, while the two other siblings had severe ID and spastic tetraplegia with athetoid movements.

Up to date, 11 other patients have been reported [4-10]. The prevalence of OCHS in consanguineous families is in favour of an autosomal recessive inheritance, but no molecular or biochemical substratum is known so far.

Here, we report a 4-year-old girl born to normal consanguineous Turkish parents with OCHS and additional findings consisting of recurrent respiratory and urinary tract infections and vertebral fusion of L4-L5. We mapped this disorder to a $10 \mathrm{Mb}$ region on chromosome (3)(q27.1q29). We discuss the genotypephenotype correlations and suggest candidate genes for this disorder. cular genetics finding in a patient OCHS. Here we discuss the genotype-phe-
Elyes Chabchoub, MD, MSc

Centre for Human Genetics, University Hospitals of Leuven Herestraat 49 B 602

BE-3000 Leuven (Belgium)

Tel. +32 1634 7990,E-Mail elyes.chabchoub@ med.kuleuven.be 
Table 1. Overview of the clinical features of patients with OCHS

\begin{tabular}{|c|c|c|c|c|c|c|c|c|c|}
\hline Clinical features & $\begin{array}{l}\text { This } \\
\text { report }\end{array}$ & $\begin{array}{l}\text { Pollazzon } \\
\text { et al. [19] }\end{array}$ & $\begin{array}{l}\text { Cross } \\
\text { et al. [1] }\end{array}$ & $\begin{array}{l}\text { Elejalde } \\
\text { et al. [30] }\end{array}$ & $\begin{array}{l}\text { Preus } \\
\text { et al. [2] }\end{array}$ & $\begin{array}{l}\text { Patton } \\
\text { et al. [8] }\end{array}$ & $\begin{array}{l}\text { Fryns } \\
\text { et al. [3] }\end{array}$ & $\begin{array}{l}\text { De Jong and } \\
\text { Fryns [5] }\end{array}$ & $\begin{array}{l}\text { Tezcan } \\
\text { et al. [9] }\end{array}$ \\
\hline Skin hypopigmentation & + & - & + & + & + & + & + & + & + \\
\hline Silver-grey/white hair & + & - & + & + & + & + & + & + & + \\
\hline Ocular anomalies & + & - & + & + & + & + & + & + & + \\
\hline Microcephaly & + & - & + & + & + & + & + & + & + \\
\hline Hypotonia & + & - & $\mathrm{NI}$ & + & NI & + & + & + & + \\
\hline Ataxia & - & - & + & + & + & + & + & + & + \\
\hline Spasticity & - & + & + & + & NI & NI & + & + & + \\
\hline Developmental delay/intellectual disability & + & + & + & + & + & + & + & + & + \\
\hline Brain malformation & - & $t^{\mathrm{a}}$ & DWM & CAo & - & CAo & DWV & DWM & DWM \\
\hline Growth retardation & + & - & + & $\mathrm{NI}$ & + & + & + & + & + \\
\hline Consanguinity/autosomal recessive inheritance & $+/+$ & $-1-$ & $+/+$ & $+/+$ & $+/+$ & $-1+$ & $+/+$ & $+/+$ & $+/+$ \\
\hline Melanocytes (microscopy) & $\mathrm{N}$ & NI & $\downarrow$ & $\mathrm{Ab}$ & NI & $\downarrow$ & $\downarrow$ & NI & $\mathrm{N}$ \\
\hline Melanosome maturation & $\mathrm{NI}$ & $\mathrm{NI}$ & $\mathrm{NI}$ & NI & NI & $\mathrm{Ab}$ & $\mathrm{Ab}$ & $\mathrm{NI}$ & $\mathrm{Ab}$ \\
\hline Seizures & - & $\mathrm{NI}^{\mathrm{b}}$ & $\mathrm{NI}$ & + & NI & - & $+{ }^{\mathrm{b}}$ & - & $+^{\mathrm{c}}$ \\
\hline Recurrent urinary tract infections/malformations & + & - & $\mathrm{NI}$ & $\mathrm{NI}$ & NI & - & NI & - & + \\
\hline Heart malformations & - & + & $\mathrm{NI}$ & NI & NI & - & - & - & + \\
\hline Blood cells/lineage anomalies & - & $\mathrm{NI}$ & - & NI & anaemia & - & - & - & VMC \\
\hline Vertebral anomalies & L4-L5 fusion & scoliosis & NI & NI & NI & - & - & - & - \\
\hline Osteoporosis & - & NI & - & - & + & + & - & - & - \\
\hline Acetabular hypoplasia & - & $\mathrm{NI}$ & - & - & + & + & - & - & - \\
\hline Karyotype & $46, \mathrm{XX}$ & $46, \mathrm{XX}$ & NI & NI & NI & $46, X Y$ & $46, X Y$ & 46,XX & NI \\
\hline
\end{tabular}

$+=$ Sign present; $-=$ sign absent; $\downarrow=$ reduced; $\mathrm{Ab}=$ abnormal; CAo = cerebral atrophy (mainly the occipital lobes); DWM = Dandy-Walker malformation; DWV = Dandy-Walker variant; $\mathrm{N}=$ normal; $\mathrm{NI}=$ not indicated; VMC = vacuolated myeloid series cells.

${ }^{a}$ Myoclonic epilepsy. ${ }^{\mathrm{b}}$ Nonspecific electroencephalographic signals without clinical manifestations. ${ }^{\mathrm{c}}$ Nonspecific white matter signals on magnetic resonance imaging.

\section{Subject and Methods}

\section{Clinical Report}

A 4-year-old girl was referred for developmental delay, multiple congenital anomalies with generalised hypopigmentation, and failure to thrive. She was born at 32 weeks of gestation by normal vaginal delivery to healthy consanguineous Turkish parents. She had a low birth weight $(1,250 \mathrm{~g})$ and suffered from recurrent respiratory and urinary tract infections. On physical evaluation, her weight $(8 \mathrm{~kg})$, height $(80 \mathrm{~cm})$ and head circumference $(41 \mathrm{~cm})$ were all below the $3 \mathrm{rd}$ centile. She showed dysmorphic features with microcephaly, sparse silver-grey hair, low frontal hairline, microphthalmia, telecanthus, blue sclera, broad nasal bridge, micrognathia, thin upper lip, joint laxity, broad hallux and partial syndactyly (fig. 1a-c). Her developmental milestones were delayed: she crawled on hands and knees at 12 months but could not walk without support. Generalised hypotonia was noticed at neurologic examination.
Skeleton X-rays showed a vertebral fusion of L4-L5 with a normal lumbosacral segment of spinal cord on magnetic resonance imaging that did not detect structural or migration anomalies of the brain apart from the microcephaly. Transthoracic echocardiography was normal. Urinary tract imaging showed nephrolithiasis with left ectopic kidney and vesicoureteral reflux grade III in the left kidney and grade II in the right one with a diverticulum of the bladder. Ureterolithotomy was successful.

Complete blood count, serum biochemistry profile and urine analyses were normal. Metabolic screening of urine and serum (urine organic acid analysis, mass spectrometry, dosage of biotidinase, phenylalanine, glucose-6-phosphate dehydrogenase, acylcarnitine) were within normal limits. Capillary zone electrophoresis of serum sialotransferrins was normal, thus excluding a congenital defect of glycosylation (CDG). Hair examination under light microscopy revealed no melanin deposit defect (table 1).

\section{Genetic Investigations}

Conventional standard G-banded karyotype at a resolution of 450 bands was performed on peripheral blood lymphocytes according to standard procedures. BAC array comparative genomic hybridisation (aCGH) at a mean resolution of $1 \mathrm{Mb}$ was performed as previously described [11]. Since only the patient's DNA was still available, fluorescence in situ hybridisation could not be performed and the aCGH data were confirmed by realtime quantitative PCR (qPCR) and completed by genotyping using $(\mathrm{CA})_{\mathrm{n}}$ repeat polymorphic marker analysis mapping to 3q27.1 (D3S1571, D3S3609, D3S3578) and to 3 q29 (D3S3669, D3S3562) which, in addition, enabled to determine the parental origin of the abnormality. We further finemapped the breakpoints using a dye-swap labelling of the patient's DNA, hybridised to a ten-fold higher resolution OGT ${ }^{\text {TM }} \mathrm{Cy}$ toSure ISCA 180k DNA oligoarray ${ }^{\circledR}(\mathrm{Ox}$ ford Gene Technology, Oxford, UK, based on a technology from Agilent ${ }^{\mathrm{TM}}$, USA) following the manufacturer's protocol [12]. 
Bioinformatic Analyses and Candidate Gene Prioritisation

The genes in the rearranged region were mapped in silico using the BIOMART tool of the Ensembl genome browser (annotation NCBI 36 from http://may2009. archive.ensembl.org/Homo_sapiens). To look for the candidate gene(s) for OCHS, we selected, in a first step, 11 known genes for hypopigmentation diseases (EDNRB, MITF, PAX3, EDN3, HPS1, AP3B1, HPS3, OCA2, GPR143, MYO5A and RAB27A), then we applied a gene prioritisation strategy using the software String v8.3 [13, 14] (available online from http://string-db. org) for an overview of the possible in silico interactions between these disease genes and the candidate genes within the rearranged region and their statistical significance. We also used the software Endeavour [14] (from http://homes.esat. kuleuven.be/ bioiuser/endeavour/index. php) to rank the candidate genes within the rearranged region using the abovementioned 11 disease genes as a training set. The model was set after internally validating the data sources as recommended by the authors [14]. In a third step, we manually investigated the genes within the candidate region using the OMIM database (from http://www.ncbi.nlm.nih.gov/ omim), the expression data resources from the BioGPS database [15] (from http:// biogps.gnf.org/\#goto=welcome) and by checking the existence of mice models from the Jackson Laboratory mouse genome database MGI (from http://www. informatics.jax.org).

\section{Results and Discussion}

By aCGH we detected an interstitial deletion of 3q27.1q29 with a maximal size of $10.094 \mathrm{Mb}$. The flanking clones are RP11-14I2 and RP11-279P10. The proximal breakpoint maps between the oligoprobes A_16_P00886023 (185,168,209 bp) and A_14_P113421 (185,203,917 bp) disrupting the ABCC5 gene (OMIM 605251). The distal breakpoint maps between the probes A_14_P113559 (195,212,832 bp) and A_16_P00900866 (195,262,297 bp) (annotation NCBI 36) (fig. 1d, e). With qPCR, we confirmed the deletion and showed that it was de novo (data not shown). Using the microsatellite markers mapping to $3 \mathrm{q}$ we confirmed the deletion and showed that the derivative chromosome 3 is paternal (data not shown). We
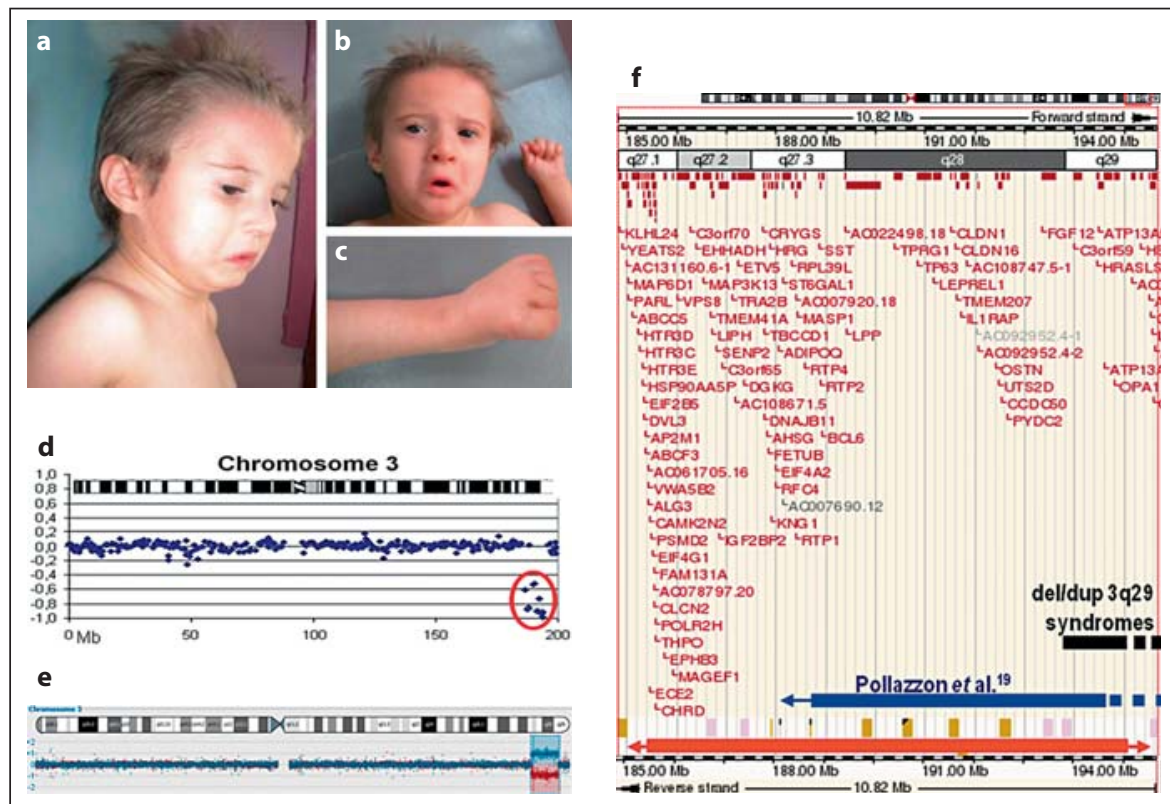

Fig. 1. a-c The patient aged 4 years showing dysmorphic features with skin and hair hypopigmentation. d Partial $1 \mathrm{Mb}$ resolution BAC aCGH data from chromosome 3 of the child displaying the $\log _{2}$ ratio plot with the deleted clones encircled in red. On the $\mathrm{x}$ axis the relative distance of the $\mathrm{BAC}$ clones from the $2 \mathrm{p}$ telomere is indicated in $\mathrm{Mb}$ with the chromosome 3 ideogram. e Partial data of chromosome 3 from the $100 \mathrm{~kb}$ resolution OGT ${ }^{\mathrm{TM}}$ CytoSure ISCA 180k DNA oligoarray displaying the dye-swap hybridisations (the Cy-5-labelled patient's DNA is represented by the red plot for the first hybridisation and the Cy-3-labelled patient's DNA by the blue plot representing the data from the dye-swap hybridisation with every coloured spot representing an oligoprobe from the arrays). $f$ A screen capture from the Ensembl database (annotation NCBI 36) showing the physical map of the deleted BAC clones and the Ensembl genes. The deletion in the present patient is delineated by the red lines and the patient reported by Pollazzon et al. [19] is represented by the blue line. The thin arrows delineate the maximum size of the deletions at the flanking probes. The del/dup 3q29 syndromes map to the black line.

mapped 107 Ensembl-annotated genes to this region (fig. 1f), with 82 protein-coding genes encompassing 61 OMIM genes, 18 genes were expressed in melanocytes and 12 genes were identified as disease-associated genes.

Our present patient has no structural brain malformations, but microcephaly and thus the clinical picture is most compatible with the Cross type of OCHS. This shows a clear overlap of the clinical features in these OCHS subtypes as illustrated in table 1.

Few reports of microscopically visible 3qter deletion patients have been published with growth retardation, hypotonia, ear abnormalities, and cognitive delay. 3 out of the 5 reported patients died at a young age [16]. In 2001, the first submicroscopic microdeletion of 3 qter was reported in 3q29 [17]. Willatt et al. [18] described 6 more cases. Characteristic features were a long and narrow face, high nasal bridge, short philtrum, a tight upper lip, and mild to moderate ID. Less frequent features were ataxic and unsteady gait, autism, microcephaly, long fingers, and chest wall deformity. This clinical description fits with the dysmorphic features of our patient. Pollazzon et al. [19] reported a 9.3 Mb deletion of 3q27.3q29 overlapping distally with the deletion in our patient but not resembling the spectrum of Cross syndrome. Moreover, unlike the deletion in our patient, the one reported by Pollazzon et al. [19] extends further distally to overlap 
with the critical region of the 3q29 deletion/duplication syndrome (fig. 1f). Interestingly, several reports were published with dup3q27q29 in patients presenting hypotonia, dysmorphic features, increased head circumference (p75) and skin hyperpigmentation [20-22]. To our knowledge, this is the first molecular genetics finding in a patient with OCHS. We assume that haploinsufficiency in chromosome $3 \mathrm{q}$ could have unravelled a mutation in a gene located in the homologous region in the 'cytogenetically normal' maternal chromosome in our patient, leading to the phenotypic manifestations of OCHS.

Neurons and melanocytes are neuroectodermal derivatives. This can explain the occurrence of brain and sensorineural anomalies and skin and hair hypopigmentation as suggested earlier [9]. When analysing in silico the genes in the deleted $3 \mathrm{q}$ region, we identified some valuable candidates for OCHS. Heterozygous mutations in the OPA1 gene induce abnormal apoptosis and cause autosomal dominant optic atrophy, sensorineural deafness and myopathy [23]. PARL interacts with OPA1 and is also involved in the regulation of apoptosis [24], so the loss of both alleles can be causal for the brain malformations and ectodermal depigmentation reported in OCHS. Furthermore, DVL3 encodes a cytoplasmic phosphoprotein regulating cell proliferation and acts as a transducer molecule for developmental processes such as segmentation and neuroblast specification [25]. Thus DVL3 can be a good candidate. On the other hand, mutations in EDN3 cause Waardenburg syndrome type $\mathrm{IV}_{\mathrm{B}}$. Mice deficient in ECE1 have reduced levels of Edn3 [26]. We think that ECE2 on 3q, a close homologue of ECE1, can also play a similar role in explaining the ectodermal hypopigmentation and cognitive disorders described in OCHS. Besides ETV5-deficient mice showed hypoplastic or missing kidneys, suggesting that ETV5 plays a role in branching morphogenesis in the developing kidney [27]. Similarly, several families with nephrolithiasis and recurrent urinary tract infections have been reported with homozygous mutations in the CLDN16 gene [28]. This may explain the urologic manifestations in OCHS. Besides, the deletion of FGF12 might be the cause of microcephaly, which is a common sign for the clinical spectrum of OCHS manifestations. A special note is to be addressed to the ALG3 gene were patients harbouring homozygous mutations had failure to thrive, epilepsy, hypotonia, marked ID, microcephaly, ocular anomalies, facial dysmorphism and reduced mannosyltransferase activity corresponding to a CDG type Id [29]. The clinical spectrum of OCHS overlaps with CDG Id, nevertheless this diagnosis was excluded by the capillary zone electrophoresis of serum sialotransferrins.

In conclusion, we report a new patient with OCHS and peculiar manifestations consisting of recurrent respiratory and urinary tract infections and vertebral fusion of L4-L5. We mapped for the first time this syndrome to $3 \mathrm{q} 27 \mathrm{q} 29$. Investigating further patients with this condition would enable fine-mapping of the locus and identification of the putative gene for OCHS.

\section{Acknowledgements}

We would like to thank the patient and her family for their precious collaboration. We are grateful to Prof. Dr. Gert Matthijs and Prof. Dr. J Jaeken for kindly providing the capillary zone electrophoresis of serum sialotransferrins test, and to Mrs. Nooshin Ardeshirdavani for her technical assistance. E. Chabchoub is a fellow of the University of Leuven (KUL-Belgium)IRO-Scholarship for $\mathrm{PhD}$ studies (IRO ID 16727 - Contract 65980).

\section{Ethics Approval}

The authors declare that informed, written consent was obtained and that the experiments comply with the current laws of Belgium and with the ethical principles of the WMA Declaration of Helsinki.

\section{Disclosure Statement}

The authors declare that they have no conflict of interest.

\section{References}

1 Cross HE, McKusick VA, Breen W: A new oculocerebral syndrome with hypopigmentation. J Pediatr 1967;70:398-406.

$\checkmark 2$ Preus M, Fraser FC, Wiglesworth FW: An oculocerebral hypopigmentation syndrome. J Genet Hum 1983;31:323-328.

3 Fryns JP, Dereymaeker AM, Heremans G, Marien J, van Hauwaert J, Turner G, Hockey A, van den Berghe $\mathrm{H}$ : Oculocerebral syndrome with hypopigmentation (Cross syndrome). Report of two siblings born to consanguineous parents. Clin Genet 1988;34: 81-84.

$\checkmark 4$ Courtens W, Broeckx W, Ledoux M, Vamosa E: Oculocerebral hypopigmentation syndrome (Cross syndrome) in a gipsy child. Acta Paediatr Scand 1989;78:806810 .
5 De Jong G, Fryns JP: Oculocerebral syndrome with hypopigmentation (Cross syndrome): the mixed pattern of hair pigmentation as an important diagnostic sign. Genet Couns 1991;2:151-155.

6 Lerone M, Pessagno A, Taccone A, Poggi G, Romeo G, Silengo MC: Oculocerebral syndrome with hypopigmentation (Cross syndrome): report of a new case. Clin Genet 1992;41:87-89.

7 Passarge E, Fuchs-Mecke S: Oculocerebral syndrome with hypopigmentation. Birth Defects Orig Artic Ser 1975;11:466-467.

$>8$ Patton MA, Baraitser M, Heagerty AH, Eady RA: An oculocerebral hypopigmentation syndrome: a case report with clinical, histochemical, and ultrastructural findings. J Med Genet 1987;24:118-122.
-9 Tezcan I, Demir E, Asan E, Kale G, Muftuoglu SF, Kotiloglu E: A new case of oculocerebral hypopigmentation syndrome (Cross syndrome) with additional findings. Clin Genet 1997;51:118-121.

10 White CP, Waldron M, Jan JE, Carter JE: Oculocerebral hypopigmentation syndrome associated with Bartter syndrome. Am J Med Genet 1993;46:592-596.

$>11$ Chabchoub E, Rodriguez L, Galan E, Mansilla E, Martinez-Fernandez ML, Martinez-Frias ML, Fryns JP, Vermeesch JR: Molecular characterisation of a mosaicism with a complex chromosome rearrangement: evidence for coincident chromosome healing by telomere capture and neo-telomere formation. J Med Genet 2007;44:250256 . 
12 Chabchoub E, Willekens D, Vermeesch J, Fryns JP: Holoprosencephaly and ZIC2 microdeletions: novel clinical and epidemiological specificities delineated. Clin Genet 2011, Epub ahead of print.

-13 Jensen LJ, Kuhn M, Stark M, Chaffron S, Creevey C, Muller J, Doerks T, Julien P, Roth A, Simonovic M, Bork P, von Mering C: STRING 8 - a global view on proteins and their functional interactions in 630 organisms. Nucleic Acids Res 2009;37:D412-D416.

14 Tranchevent LC, Barriot R, Yu S, Van Vooren S, Van Loo P, Coessens B, De Moor B, Aerts $S$, Moreau Y: Endeavour update: A web resource for gene prioritization in multiple species. Nucleic Acids Res 2008;36:W377-W384.

-15 Wu C, Orozco C, Boyer J, Leglise M, Goodale J, Batalov S, Hodge CL, Haase J, Janes J, Huss JW 3rd, Su AI: BioGPS: an extensible and customizable portal for querying and organizing gene annotation resources. Genome Biol 2009;10:R130.

16 Chitayat D, Babul R, Silver MM, Jay V, Teshima IE, Babyn P, Becker LE: Terminal deletion of the long arm of chromosome 3 [46,XX,del(3)(q27->qter)]. Am J Med Genet 1996;61:45-48.

- 17 Rossi E, Piccini F, Zollino M, Neri G, Caselli D, Tenconi R, Castellan C, Carrozzo R, Danesino C, Zuffardi O, Ragusa A, Castiglia L, Galesi O, Greco D, Romano C, Pierluigi M, Perfumo C, Di Rocco M, Faravelli F, Dagna Bricarelli F, Bonaglia M, Bedeschi M, Borgatti R: Cryptic telomeric rearrangements in subjects with mental retardation associated with dysmorphism and congenital malformations. J Med Genet 2001;38:417-420.
18 Willatt L, Cox J, Barber J, Cabanas ED, Collins A, Donnai D, FitzPatrick DR, Maher E, Martin H, Parnau J, Pindar L, Ramsay J, ShawSmith C, Sistermans EA, Tettenborn M, Trump D, de Vries BB, Walker K, Raymond FL: 3q29 microdeletion syndrome: clinical and molecular characterization of a new syndrome. Am J Hum Genet 2005;77:154-160.

19 Pollazzon M, Grosso S, Papa FT, Katzaki E, Marozza A, Mencarelli MA, Uliana V, Balestri P, Mari F, Renieri A: A 9.3 Mb microdeletion of 3q27.3q29 associated with psychomotor and growth delay, tricuspid valve dysplasia and bifid thumb. Eur J Med Genet 2009;52:131-133.

20 Kroisel PM, Petek E, Wagner K: Skin pigmentary anomalies in a mosaic form of partial tetrasomy 3q. J Med Genet 2000;37:723-725.

21 Portnoi MF, Boutchnei S, Bouscarat F, Morlier G, Nizard S, Dersarkissian H, Crickx B, Nouchy M, Taillemite JL, Belaich S: Skin pigmentary anomalies and mosaicism for an acentric marker chromosome originating from 3q. J Med Genet 1999;36:246-250.

22 Teshima I, Bawle EV, Weksberg R, Shuman C, Van Dyke DL, Schwartz S: Analphoid 3qter markers. Am J Med Genet 2000;94:113-119.

23 Cornille K, Milea D, Amati-Bonneau P, Procaccio V, Zazoun L, Guillet V, El Achouri G, Delettre C, Gueguen N, Loiseau D, Muller A, Ferre M, Chevrollier A, Wallace DC, Bonneau D, Hamel C, Reynier P, Lenaers G: Reversible optic neuropathy with OPA1 exon $5 \mathrm{~b}$ mutation. Ann Neurol 2008;63:667-671.

24 Cipolat S, Rudka T, Hartmann D, Costa V, Serneels L, Craessaerts K, Metzger K, Frezza C, Annaert W, D’Adamio L, Derks C, Dejaegere T, Pellegrini L, D'Hooge R, Scorrano L, De Strooper B: Mitochondrial rhomboid PARL regulates cytochrome $\mathrm{c}$ release during apoptosis via OPA1-dependent cristae remodeling. Cell 2006;126:163-175.
25 Klingensmith J, Nusse R, Perrimon N: The Drosophila segment polarity gene dishevelled encodes a novel protein required for response to the wingless signal. Genes Dev 1994;8:118-130.

26 Clouthier DE, Hosoda K, Richardson JA, Williams SC, Yanagisawa H, Kuwaki T, Kumada M, Hammer RE, Yanagisawa M: Cranial and cardiac neural crest defects in endothelin-A receptor-deficient mice. Development 1998;125:813-824.

27 Lu BC, Cebrian C, Chi X, Kuure S, Kuo R, Bates CM, Arber S, Hassell J, MacNeil L, Hoshi M, Jain S, Asai N, Takahashi M, Schmidt-Ott KM, Barasch J, D'Agati V, Costantini F: Etv4 and Etv5 are required downstream of GDNF and Ret for kidney branching morphogenesis. Nat Genet 2009; 41:1295-1302.

28 Muller D, Kausalya PJ, Meij IC, Hunziker W: Familial hypomagnesemia with hypercalciuria and nephrocalcinosis: Blocking endocytosis restores surface expression of a novel Claudin-16 mutant that lacks the entire Cterminal cytosolic tail. Hum Mol Genet 2006;15:1049-1058.

29 Stibler H, Stephani U, Kutsch U: Carbohydrate-deficient glycoprotein syndrome - a fourth subtype. Neuropediatrics 1995;26: 235-237.

$>30$ Elejalde BR, Holguin J, Valencia A, Gilbert EF, Molina J, Marin G, Arango LA: Mutations affecting pigmentation in man: I. Neuroectodermal melanolysosomal disease. Am J Med Genet 1979;3:65-80. 